\title{
The Conservationist Principle under International Humanitarian Law versus a Transformative Occupation in a Human Rights Context*
}

\author{
María Helena Carbonell Yánez ${ }^{* *}$ \\ DOI: https://doi.org/10.22304/pjih.v6n1.a2
}

Submitted: February 27, 2019 | Accepted: April 23, 2019

\begin{abstract}
This article presents a discussion about the necessary evolution of the law of occupation facing the obligations set for by the International Human Rights regime, based on the law of State responsibility. In the first section of this two-part study, the article delivers a state of the art through the analysis of doctrine and both universal and regional jurisprudences on State responsibility based on the extraterritorial application of International Human Rights Law. On the second part, the article provides analysis on temporal (beginning and end) and territorial aspects of occupation that have a direct impact on the obligation to respect and to ensure the rights of every subject to the State's jurisdiction. In the final section, the article discusses the clash between the traditional conservationist principle and the transformative occupation principle. This study employed a logic-inductivist method. To conclude the discussion, this study is in the position that the conservative principle under International Humanitarian Law is considered archaic; and should give way to better protection of human rights in an international occupation context.
\end{abstract}

Keywords: human rights law, international humanitarian law, law of occupation.

\section{Prinsip Konservasionis dalam Hukum Humaniter Internasional vs. Okupasi Transformatif dalam Konteks Hak Asasi Manusia}

\begin{abstract}
Abstrak
Artikel ini menyajikan diskusi tentang perkembangan hukum okupasi dalam menghadapi kewajiban yang ditetapkan oleh rezim Hukum HAM Internasional, berdasarkan tanggung jawab negara. Bagian pertama artikel membahas tentang keadaan terkini melalui analisis doktrin dan yurisprudensi universal dan regional terhadap tanggung jawab negara berdasarkan penerapan asas ekstrateritorial dalam Hukum HAM Internasional. Bagian kedua penulis menganalisis aspek temporal dan teritorial dalam okupasi yang memiliki
\end{abstract}

PADJADJARAN Journal of Law Volume 6 Number 1 Year 2019 [ISSN 2460-1543] [e-ISSN 2442-9325]

* This paper is based on a previous work entitled "State Responsibility for Human Rights Violations Committed by 'Puppet Governments': Conservationist Principle under IHL versus Obligation to Achieve the Full Realization of Every Human Right".

** Lawyer by the Pontificia Universidad Catolica del Ecuador, diploma in human rights and public policies (Universidad del Rosario, Bogotá), LL.M. (Geneva Academy of International Humanitarian Law), Ph.D (Universidad Andina Simón Bolivar), Professor, maria.helena.carbonell@gmail.com 
dampak langsung pada kewajiban untuk menghormati hak-hak setiap individu yang tunduk pada yurisdiksi negara. Pada bagian terakhir, artikel ini membahas tentang perbedaan antara prinsip konservasionis tradisional dengan prinsip okupasi transformatif. Melalui metode logic-inductivist, artikel ini menyimpulkan bahwa prinsip konservasionis dalam kerangka Hukum Humaniter Internasional telah ketinggalan jaman dan upaya lain harus dilakukan untuk memberikan perlindungan HAM yang lebih baik ketika okupasi internasional terjadi.

Kata kunci: hukum Hak Asasi Manusia, hukum humaniter internasional, hukum pendudukan.

\section{A. Introduction}

State responsibility is based on the existence of an internationally wrongful act attributable to the state. This act is contrary to what is expected from the state in regards to its international obligations. The nature or origin (the area of law that it regulates) of these obligations is irrelevant when it comes to determining its responsibility under Public International Law. In this background, International Humanitarian Law, broadly, is a set of rules that aims to limit the negative effects of an armed conflict regulating different scenarios that may arise when one occurs. One of these is belligerent occupation, i.e. the temporary possession of territory by an occupying power. Another area of law that contains clear obligations for state is the International Human Rights Law, a body of rules that seeks the respect, fulfillment, and promotion of human rights in a national or international level. The International Human Rights Law applies not only in times of peace but also during an international or non-international armed conflict.

Both branches contain clear obligations for state in times of an armed conflict, which may generate situations where responsibility arises. Some of those rules can require state to act in ways that can be contradictory. If non-compliance with any of those obligations generates the responsibility of the State, which one prevails? How should the State solve this impasse? To clear up this problem, this article presents a two-part study that focuses on the analysis of the scope of the rules on belligerent occupation and its relation with the International Human Rights Law. The first part presents the general elements of State responsibility linked with the extraterritorial application of the International Human Rights Law in a belligerent occupation scenario. The second one discusses the conservationist principle and the transformative occupation proposal from a human rights perspective.

\section{B. State Responsibility from an Extra-Territorial Application of Human Rights Law in a Belligerent Occupation Scenario}

1. General Aspects of State Responsibility Under Public International Law 
State responsibility arises from an internationally wrongful act that is attributable to the state in accordance with the rules of International Law. An internationally wrongful act is an action or omission that constitutes a breach of the international obligation of the state. ${ }^{1}$ The International Law Commission explains that "the essence of an internationally wrongful act lies in the non-conformity of the State's actual conduct with the conduct it ought to have adopted in order to comply with a particular international obligation". ${ }^{2}$

To determine the scope of the conduct expected from the State, attention must be paid to the obligation contained in the primary rule. The nature of the obligation (treaties, customary law, and judicial decisions...) is irrelevant to determine the existence of a breach. State responsibility may arise independently due to the origin of such an obligation, but its scope will be determined in the primary rule. It is only required that the obligation is in force at the time of its breach. ${ }^{3}$ This means that the primary rule had to be in force, i.e. binding for the State when the conduct occurred. Once its existence is proven, it must be attributed to the State. According to the rules of the International Law, the conduct of its organs is attributable to the State, even if they are acting ultra vires. ${ }^{4}$ The national legislation can determine if a person or organ is an agent of the State or if it acted ultra vires. There must be a reasonable link between the conduct, the actor, and the State so the conduct can be attributed to the State. This does not affect the fact that the national organization of the government is irrelevant to International Law.

There are other circumstances in which an action or omission carried out by a person or entity, which cannot be considered as an organ of state in national legislation, can be attributed to state. These forms of attribution are not relevant for the study. However, for further clarification, it is relevant to analyze the ILC Commentaries of the articles on state responsibility ${ }^{5}$ and the subsequent study developed by rapporteur James Crawford. ${ }^{6}$

As mentioned before, the obligation of state can emanate from different areas of law, including the Human Rights Law. The following paragraphs present an

1 International Law Commission, Draft articles on Responsibility of States for Internationally Wrongful Acts, with Commentaries, 2001; M. Sorensen, Manual de Derecho Internacional Público, Mexico: Fondo de Cultura Económica, 2011, pp. 507-508; M. N. Shaw, International Law, United Kingdom: Cambridge University Press, 2008, pp. 781-82; J. A. Travieso, Derecho Internacional Público Buenos Aires: Abeledo Perrot, 2012, p. 522.

2 International Law Commission, op.cit., p. 54.

$3 \quad$ lbid., pp. 57-59.

$4 \quad$ Ibid., pp. 4-7; Marco Monroy Cabra, Derecho Internacional Público, Colombia: Ed. Temis, 2011, p. 571; Max Sorensen, Manual de Derecho Internacional Público, p. 516; James Crawford, State responsibility: The General Part, United Kingdom: Cambridge University Printing House, 2013, pp. 117-124; Inter-American Court of Human Rights (IACHR), Velásquez Rodríguez Case, Judgement, Ser. C No. 4, 164, 1988.

5 International Law Commission, "Draft articles on Responsibility of States for Internationally Wrongful Acts, with Commentaries", op.cit.

6 James Crawford, op.cit. 
analysis of the obligations imposed to state under this area to determine when international state responsibility may arise. Considering the belligerent occupation scenarios, special interest will be its extraterritorial application.

\section{State Responsibility for Human Rights Violations and the Extraterritorial Application of Human Rights Law}

In International Human Right Law, there are two major obligations common to all human rights, which are to respect and to ensure (to fulfill) the free and full exercise of the rights of all person subject to the jurisdiction of state. ${ }^{7}$ The duty bearer (i.e. state) will be responsible for a human right violation upon failure of compliance. ${ }^{8}$ Article $1(1)$ of the American Convention on Human Rights states that the State has the duty to respect and ensure the rights set for in the Convention to every person subject to its jurisdiction. Article 2 of the International Covenant on Civil and Political Rights (ICCPR) establishes the same obligations in similar terms.

To monitor the implementation of human rights treaties, States have created several judicial and quasi-judicial organs. In the Americas, the Inter-American Human Rights Commission and Court; in Europe, the European Court of Human Rights is the judicial organ that monitors State's compliance with their human rights obligations; and, in a universal level, the treaty-based organs carry out this task. While doing so, these international organs have determined the content of the State's obligations (even if the wording of the treaties may vary, there are some coincident elements).

The obligation to respect implies an absolute prohibition imposed on state, which forces it to avoid carrying out any conduct leading to any human rights violation. In this particular case, the prohibition binds every state organ. ${ }^{9}$ The second obligation requires states parties to take affirmative measures of a judicial, legislative, and executive nature, "to organize the governmental apparatus and, in general, all the structures through which public power is exercised so that they are capable of juridically ensuring the free and full enjoyment of human rights" ${ }^{10}$ The

Article 1 of American Convention on Human Rights, 1969.

IACHR, loc.cit.

9 Human Rights Committee, "General Comment 31: The Nature Of The General Legal Obligation Imposed On State Parties", 2004, p. 4; María Helena Carbonell, "El deber del Estado de reparar las violaciones de derechos humanos", Cálamo Revista de Estudios Jurídicos, 2014, p. 140; Tara Melish, Protecting Economic, Social and Cultural Rights in the Inter-American Human Rights System: A Manual on Presenting Claims, Ecuador: CDES, 2002, pp. 159-60; Rolando Gialdino, Derecho internacional de los derechos humanos: principios, fuentes, interpretación y obligaciones, Buenos Aires: Abeledo Perrot, 2013, pp. 499-502. 
duty to ensure consists of five principle of state's obligations: to prevent, to investigate, to sanction, to remedy, and to ensure the minimum core content. ${ }^{11}$

The obligations regarding human rights imposed by treaties makes no reference to state's territory but to its jurisdiction when it comes to its duty to respect and fulfill human rights. Traditionally, the exercise of its jurisdiction is mainly territorial but there is also the possibility that the State exercises it outside its boundaries. This is not a common situation, and international case law has helped clarify the conditions necessary for state to exercise jurisdiction extraterritorially. The following paragraphs analyze the approaches taken by different tribunals and supervising organs regarding this subject in cases where a state exercised or not jurisdiction over a foreign territory where violations occurred.

\section{a. Universal system}

Based on Article 2 of the ICCPR, the Human Rights Committee ${ }^{12}$ has affirmed that even if a state's jurisdiction is mainly territorial, this provision is also applied outside the territory of a high contracting party when this one exercises jurisdiction over another territory. ${ }^{13}$ In its General Comment 31 (hereinafter "GC31"), the Committee explains as follows.

State party must respect and ensure the rights laid down in the Covenant to anyone within the power or effective control of that State Party, even if not situated within the territory of the State Party. (...) This principle also applies to those within the power or effective control of the forces of a State Party acting outside its territory, regardless of the circumstances in which such power or effective control was obtained, such as forces constituting a national contingent of a State Party assigned to an international peace-keeping or peace-enforcement operation ${ }^{14}$

The Committee has also focused on the case of belligerent occupation in its General Comment 29 (hereinafter CG29) that "the Covenant applies also in situations of armed conflict to which the rules of international humanitarian law

\footnotetext{
11 Tara Melish, op.cit., p. 170; María Helena Carbonell, op.cit., pp. 140-41; Rolando Gialdino, op. cit., pp. 503515.

12 It is the UN treaty-based body that monitors the implementation of the ICCPR.

13 Human Rights Committee, Sergio Euben Lopez Burgos v. Uruguay, Communication No. R.12/52, U.N.Doc. Supp. 40 (A/36/40), at 176, 1981.; Human Rights Committee, Lilian Celiberti de Casariego v. Uruguay, Communication No. 56/1979; Human Rights Committee, "General Comment 31: The nature of the general legal obligation imposed on State Parties", p. 10.

14 Human Rights Committee, "General Comment 31: The nature of the general legal obligation imposed on State Parties", p. 10.
} 
are applicable". ${ }^{15}$ In the face of its jurisprudence, it can be concluded that the Committee has accepted that a state has jurisdiction over "anyone within its power or effective control". This implies that it has to comply with its obligations under the ICCPR when it exercises effective control over a territory, no matter how the control is gained.

The International Court of Justice, in its Advisory Opinion of the Legal consequences of the construction of a wall in the occupied Palestinian territories, ${ }^{16}$ uses the same approach as the Human Rights Committee. It focuses on the applicability of the ICCPR, the International Covenant on Economic, Social and Cultural Rights, and the Convention on the Rights of the Child on the occupied Palestinian territories. The Court concludes that Human Rights Law is also valid in a territory that is considered 'occupied' because it is under the control of an occupying power. The ICJ admits that "while the jurisdiction of state is primarily territorial, it may sometimes be exercised outside the national territory". ${ }^{17}$ It recognizes that the object and purpose of the ICCPR can be hindered if a restrictive approach (strictly territorial approach) of the term jurisdiction is applied. The same line of thought is applied to the Convention on the Rights of the Child. ${ }^{18}$ Concerning the ICESCR, the Court determines that even if there is no provision regarding its territorial application, nothing excludes the possibility of an extraterritorial application of its provisions. Furthermore, noting the jurisprudence of the Committee on Economic, Social, and Cultural Rights, the Court recognizes that the Occupying Power, Israel, "is bound" by the provisions of the ICESCR on the occupied Palestinian territories". ${ }^{19}$

In the case concerning the armed activities on the territory of the Congo (the Democratic Republic of the Congo v. Uganda) ${ }^{20}$ (Congo v. Uganda case), the Court stays in line with its previous jurisprudence. It recalls that the protection of human rights instruments does not cease during an armed conflict or the belligerent occupations that may follow. If the provisions of the human rights treaty are in force for the occupying power, it must comply with them if the territory is under its effective control. ${ }^{21}$

\footnotetext{
15 Human Rights Committee, "General Comment 29: derogation during a state of emergency (article 4)", 2001, p.3.

16 See International Court Justice (ICJ), Legal consequences of the construction of a wall in the occupied Palestinian territories, Advisory Opinion, 2004.

17 Ibid., p. 109.

lbid., p. 113.

lbid., p. 112.

20 See ICJ, Case concerning the armed activities on the territory of the Congo, Democratic Republic of the Congo v. Uganda, Judgement 2005.

21 Ibid., pp. 215-16.
} 
In its jurisprudence, the ICJ has dealt with the problems arising from the extraterritorial applications of the Human Rights Law in cases of belligerent occupation. It has concluded that the conduct of the occupying power must be in accordance with its international obligations when the territory is under its effective control.

\section{b. Regional system}

The Inter American Commission of Human Rights has analyzed the extraterritorial applicability of the Human Rights Law in the cases of Coard and Alejandre et al.. The Coard case dealt with the arrest and the trial of the seventeen claimants by USA forces during the occupation of Grenada in 1983. The Commission did not openly classify the situation as an occupation but applied provisions of Geneva Convention IV, which deal with occupied territories along the relevant provisions of the American Declaration of the Rights and Duties of Man. It referred to the extraterritorial applicability of the Declaration in the following statement.

American State is obliged to uphold the protected rights of any person subject to its jurisdiction. While this most commonly refers to persons within a state's territory, it may, under given circumstances, refer to conduct with an extraterritorial locus where the person concerned is present in the territory of one State, but subject to the control of another State - usually through the acts of the latter's agents abroad. In principle, the inquiry turns not on the presumed victim's nationality or presence within a particular geographic area, but on whether, under the specific circumstances, the State observed the rights of a person subject to its authority and control. ${ }^{22}$ (emphasis added)

In the case of Alejandre et al., a Cuban military aircraft downed two civilian airplanes belonging to the organization "Brother to the rescue" in February 1996. The airplanes were in international airspace when they were fired. Analyzing its competence ratione loci, the same organ states that

Under certain circumstances the Commission is competent to consider reports alleging that agents of an OAS member state have violated human rights protected in the inter-American system, even when the events take place outside the territory of that state. In fact, the Commission would point out that, in certain cases, the exercise of its jurisdiction over extraterritorial events is not only consistent with but required by the applicable rules. ${ }^{23}$ 
The Commission used the same approach in the case of Coard, requiring that the person is subject to the authority and control of the State. However, it did not define what both terms meant in the cases.

In Europe, Article 1 of the European Convention for the Protection of Human Rights and Fundamental Freedoms states that the "High Contracting Parties shall secure to everyone within their jurisdiction the rights and freedoms defined in Section I of (the) Convention." 24 The European Court of Human Rights has interpreted the terms "within its jurisdiction" in its case law. It reaffirmed that even if jurisdiction is mainly territorial, the State can exercise it extra-territorially in exceptional circumstances. In the Loizidou case, when dealing with the Turkish occupation of Northern Cyprus, the Court states, "the concept of 'jurisdiction' under Article 1 is not restricted to the national territory of the High Contracting Parties." 25 It focuses on the responsibility of state arising from human rights violations committed outside its territory.

The responsibility of Contracting Parties can be involved because of acts of their authorities, whether performed within or outside national boundaries, which produce effects outside their own territory. Bearing in mind the object and purpose of the Convention, the responsibility of a Contracting Party may also arise when as a consequence of military action - whether lawful or unlawful - it exercises effective control of an area outside its national territory. The obligation to secure, in such an area, the rights and freedoms set out in the Convention derives from the fact of such control whether it be exercised directly, through its armed forces, or through a subordinate local administration. ${ }^{26}$ (Emphasis added)

The Court, in the Issa et al. case, analyzed the possible extraterritorial exercise of jurisdiction by Turkish agents in Iraq that supposedly ended with the deaths of several Iraqi nationals. The Court reaffirmed that, in some circumstances, jurisdiction could be exercised outside the national borders but it required a degree of control that failed to exist in the Issa case. It was never proved that the victims died by Turkish fire. The Court reaffirmed its previous conclusion and added that when dealing with the degree of control necessary for affirming that a state's control over an occupied territory is an overall control. Accordingly, there is no need to demonstrate that the government exercised a detailed control over the policies and actions of the authorities of the territory where the violations occur

Convention for the Protection of Human Rights and Fundamental Freedoms as amended by Protocol No. 11, s. f.

25 See European Court of Human Rights (ECtHR), Loizidou vs. Turkey, 62, 1995.

26 Ibid. 
but an overall control will be sufficient. ${ }^{27}$ For the Court, two situations must be distinguished. In the case of a territory, if a state exercises control outside its national territory, the later could be considered to fall within the state's jurisdiction. In the case of an individual, the Court considers that someone is within the jurisdiction of state if the later exercises effective authority over the person.

The Court has declared that there must be a link between the conduct carried out and the responsible state under whose jurisdiction the victim is. This link did not present in the Saddam Hussein case. The former president of Iraq denounced the alleged violation of several provisions of the ECHR due to his arrest, detention, and transfer to the Iraqi authorities and about his ongoing trial and its outcome. The case was brought against Albania, Bulgaria, Croatia, the Czech Republic, Denmark, Estonia, Hungary, Iceland, Ireland, Italy, Latvia, Lithuania, the Netherlands, Poland, Portugal, Romania, Slovakia, Slovenia, Turkey, Ukraine, and the United Kingdom (The Coalition). The Court established that even if the USA had a great deal of control over the operations, each state had carried out specific actions regarding the alleged breach. It concluded that a direct link between the conduct and the state exercising control had to exist: the person had to be strictly under its jurisdiction. ${ }^{28}$

As seen in the previous paragraphs, the international tribunals have admitted the possibility of an extraterritorial application of various human rights instruments. This occurs when the person or persons are placed under the control (the degree of control varies in the jurisprudence of the different tribunals) and state responsible for the violation. This is the case of belligerent occupation where an occupying power exercises control over another territory. Having proven that state has to comply with the obligations contained in Human Rights Law, things are getting complicated when these obligations clash with other areas of law, especially the International Humanitarian Law (a field that regulates belligerent occupation).

\section{General Considerations on The Law of Occupation}

There are some considerations. First, occupation has mainly an international character as it does not occur in a non-international armed conflict (NIAC). According to Gasser, the statement, "in a non-international armed conflict, the conquest by the government forces of territory held by the rebels does not constitute 'occupation' but the reestablishment of control which has been lost by

27 See ECtHR, Issa and others v. Turkey, Chamber Judgement, 2004, paragraph 69-71.

28 See ECtHR, Saddam Hussein v. Albania, Bulgaria, Croatia, the Czech Republic, Denmark, Estonia, Hungary, Iceland, Ireland, Italy, Latvia, Lithuania, the Netherlands, Poland, Portugal, Romania, Slovakia, Slovenia, Turkey, Ukraine and the United Kingdom, Admisibility decision, 2006. 
the government"29, does not amount to belligerent occupation. Second, the applicability of the law of occupation is a strict matter of facts ${ }^{30}$ and will not depend on the possible justifications that one of the parties may present for occupying a particular territory. Third, the application of the law of occupation is irrelevant for the classification of the territory. Therefore, the status of the occupied territory, before its occupation, is irrelevant for the application of the law of occupation. ${ }^{31}$ Fourth, the will of the parties involved is not relevant for the application of the law of occupation, hence a formal declaration of occupation is not necessary for the rules on occupation to apply, and its application will not be altered by any agreements settled by the parties.

\section{a. Beginning of occupation}

It is necessary to focus on the temporal matters that are relevant to the application of the law of belligerent occupation. As previously stated, the Human Rights Law is applicable to situations when state exercises jurisdiction extraterritorially and an occupying power exercises jurisdiction in the territory it occupies. Article 42 of The Hague Regulations states that a "territory is considered occupied when it is actually placed under the authority of the hostile army". This article has been interpreted in two main different ways according to the meaning given to the degree of control over the territory.

The first one has a restrictive understanding of the general rule, which is the ability to exercise control over the territory and its inhabitants. It is a prerequisite for classifying a situation as occupation. ${ }^{32}$ There are two requisites for establishing if a certain territory is under belligerent occupation: (1) the former government can no longer exercise its authority; and (2) the occupying power is able to exercise its own authority in the territory. The kind of authority referred to includes the ability to restore law and order and to fulfill its duties under Geneva Convention IV. In addition, it includes the possibility to intern protected persons for imperative security reasons and to fulfill the requirements for the conditions of their internment. ${ }^{33}$

\footnotetext{
29 Hans-Peter Gasser y Knut Dörmann, Protection of the civilian population, in Dieter Fleck (ed.), The Handbook of International Humanitarian Law, UK: OUP, 2013, p. 543.

$30 \quad$ Ibid., p. 269.

31 Adam Roberts, "What is military occupation?", British Yearbook of International Law, Vol. 55 No. 1, 1984, p. 254; Gasser y Dörmann, "Protection of the civilian population", p. 244; Article 1(3) of Additional Protocol to the Geneva Conventions of 12 August 1949 and Relating to the Protection of Victims of International Armed Conflicts, 1977.

32 Hans-Peter Gasser y Knut Dörmann, op.cit., p. 243.

33 Geneva Convention Relative to the Protection of Civilian Persons in Time of War of August of 1949, 1949, p. 78.
} 
a situation of occupation exists whenever a party to a conflict is exercising some level of authority or control over territory belonging to the enemy territory necessary to enable it to discharge all the obligations imposed by the law of occupation, i.e. that the invading power must be in a position to substitute its own authority for that of the government of the territory. ${ }^{34}$

Accordingly, if the occupying power is unable to exercise and to fulfill its obligations under the relevant IHL instruments, the situation would not amount to occupation hence the law of occupation would not be applied. The people in that territory would be protected by other provisions of the IHL instruments in force and by rules with a customary nature.

On the other hand, Pictet and the International Committee of the Red Cross (ICRC) take a broader approach. The commentary to Article 6 of Geneva Convention IV states that "there is no intermediate period between what might be termed the invasion phase and the inauguration of a stable regime of occupation". 35

A situation of occupation exists whenever a party to a conflict is exercising some level of authority or control over territory belonging to the enemy which is lower than the one required by the restrictive approach. So, for example, advancing troops could be considered an occupation, and thus bound by the law of occupation during the invasion phase of hostilities. ${ }^{36}$

It says that "invasion itself is not occupation; and if it consists on a mere raid or a simple passage across territory, it may not lead to occupation". 37 "In some cases, there may be occupations which do not begin with invasions. Foreign forces may be stationed in a territory by international agreement (peacekeeping, defense force, or other), and then later go beyond that role".38 The actual presence of the troops in a territory is an indicator but not necessarily constitutive element of occupation.

There is also the interpretation made by international and national tribunals for determining when occupation exists. The Trial Chamber of the International Criminal Tribunal for the former Yugoslavia, in Prosecutor v. Mladen Naletilić, a.k.a. "Tuta" and Vinko Martinović, a.k.a. "Štela", mentioned a list of possible

Daniel Thürer, "Current Challenges to the Law Of Occupation", Proceedings of the Bruges Colloquium: Current Challenges to the law of occupation, Bruges, 2005, pp. 9-15.

35 See commentary of Article 6 of Fourth Geneva Convention in Jean Pictet, The Geneva Conventions of 12 August 1949 Commentary - IV Geneva Convention relative to the Protection of Civilians Persons in Time of War, Geneva: ICRC, 1958, p. 60.

37 Adam Roberts, "Transformative military occupation: applying the laws of war and human rights", American Journal of International Law, Vol. 100, 2006, p. 256.

38 Ibid., p. 257. 
guidelines for qualifying a situation as occupation. It required "the occupying power [to] be in a position to substitute its own authority for that of the occupied authority, which must have been rendered incapable as functioning publicly", or that a "temporary administration has been established over the territory". 39 Confirming this, in the same case, the Tribunal's Trial Chamber states that the "law of occupation only applies to those areas actually controlled by the occupying power and ceases to apply where the occupying power no longer exercises an actual authority over the occupied area". ${ }^{40}$ The approach taken requires a high degree of control than the one used by the ICRC and seems to be in accordance with the provisions of The Hague Regulation. Even so, the Tribunal clarified that to establish whether the law of occupation applies it has to mediate a case-by-case study.

It can be concluded that there are different positions regarding the beginning of occupation. However, the tribunals and scholars agree that invasion is not itself occupation and will not make the law of occupation applicable because the territory will not be under the effective control of state. If this restrictive approach should be followed, state would not be responsible for the non-compliance with its international obligations on human rights, having in mind that the territory would not fall in its jurisdiction. To assure some degree of protection, a case-by-case study is needed to determine if the person or persons were directly under the control of state agents when the violation occurred. If such, the territory may fall outside the jurisdiction of state. However, the person may be under its authority and control hence making state responsible for human rights violations committed against that person.

\section{b. End of occupation}

As mentioned before, the temporal aspect of occupation is an essential element of its definition. Sovereignty remains in the hands of the local authority that is unable to exercise it. Sovereignty is not transferred to the occupier, which exercises temporal and provisional control over a territory because its jurisdiction over the territory is supposed to be temporal. ${ }^{41}$ Having this in mind, it must remember that an occupation can be ended in many ways. The most common is retreat of occupant force or when they are driven out. ${ }^{42}$ However, some cases are more difficult, for example, when an occupant has not withdrawn from a territory

\footnotetext{
39 International Criminal Tribunal for Yugoslavia (ICTY), Prosecutor v. Mladen Naletilic and Vinko Martinovic, Trial Chamber, Merits, IT-98-34-T, 2003, p. 217.

0 Ibid., pp. 217-218.

41 Hans-Peter Gasser y Knut Dörmann, op.cit., p. 270, 273, 284.

42 Adam Roberts, op.cit., p. 257.
} 
but the application of the law of occupation is contested due to an authorization given by local authority exercising its sovereignty again. The latter reaffirms the idea that the presence of foreign forces in a territory is an indicative element that occupation exists but it is not a constitutive element of occupation. One example can be the presence of the US-led coalition forces in Iraq after the so-called end of occupation (2004).

Article 6 of the Geneva Convention IV describes another way of the end of an occupation, namely fading away. According to the Article, the application of the law of occupation "shall cease one year after the general close of military operations" except for a limited number of provisions regarding mainly the rights of "regular" persons and the rights of protected persons.

The temporal aspect of occupation is relevant for this study because of the impact on the capacity to fulfill the obligations under IHL and under Human Rights Law. For example, following the first or second approach about the beginning of occupation, the obligations ${ }^{43}$ may be divided into two categories: (1) ones that can be fulfilled immediately; and (2) ones that require longer time. The first category includes (1) the prohibition of torture (Article 3 of the Geneva Conventions); (2) the prohibition of terror (Article 31 of GC IV); (3) the prohibition to take hostages (Article 34 of GC IV); (4) the obligation not to carry out attacks on the civilian population as way of reprisals (Article 46 of The Hague Regulations and 51(6) of AP I), (5) the prohibition of discrimination (Article 27(3) GCIV), and (6) the obligation of humane treatment (Article 27(1) GC IV). On the other hand, other obligations may require a longer presence of occupying power in the territory; for example, the obligation to supply the local population with basic needs (Articles 55(1) GC IV and Article 69(1) AP1).

The time that an occupying power presents in an occupied-territory has a direct effect on its ability to fulfill obligations, not only by IHL but also by the Human Rights Law. Achieving the full realization of every human right (where state exercises jurisdiction) is a process that may take a while and so their fulfillment will depend on the time for the occupying power to introduce changes on the occupied territory and the changes that IHL allows it to make. Despite this, its temporal presence is not an excuse to avoid fulfilling the obligation to take steps towards the full realization of every human right in the occupied territory. It implies an obligation of immediate effect and the lack of resources and the temporal presence in the territory are not acceptable excuses not to comply with this obligation.

The presence of the occupying power may face two scenarios regarding its human rights obligations. The first one considers that human rights standards in

43 In the Geneva Convention IV and Additional Protocol I to the Geneva Conventions of 12 August 1949 and related to the Protection of Victims of International Armed Conflicts 
the occupied territory are consistent with the international obligations of the occupying power. When national legislation is compatible with Human Rights Law standards, the occupying power won't have to worry about introducing any changes. The second scenario, on the other hand, faces a situation where human rights standards in the occupied territory are inconsistent with the international obligations of the occupying power. There is a common obligation to all human rights to achieve its progressive realization (even if this obligation has been developed for economic, social and cultural rights, it can be suggested that it extends also to civil and political rights). Such obligation implies that state has to take steps for the full realization of every human right within its jurisdiction. ${ }^{44}$ Even if it is recognized that full realization of every right is not immediately achieved, the occupying power's obligation to take steps is of immediate effect. The failure to do so will give rise to state responsibility to comply with its international obligation. The following section discusses this obligation compared to the strict limitations that the IHL imposes on occupying power.

\section{Clash Between the IHL and Human Rights Law Obligations: Conservationist Principle vs Transformative Occupation Principle}

\section{Conservationist Principle under International Humanitarian Law}

The conservationist principle under the IHL requires that occupying power does not change the status quo of the occupied territory. This is based on the temporal aspect of occupation and, therefore, the law of occupation aims to protect the inhabitants of the occupied territory from unnecessary burdens and trauma. occupying power only exercises jurisdiction temporarily and is not the sovereign and, therefore, cannot introduce disproportionate changes in the occupied territory.

The conservative principle and its limits are present in Article 43 of The Hague Regulations and Article 64 of the Geneva Convention IV and are based on the temporal nature of occupation. The changes imposed by the Occupying Power should be "based solely on the military strength of the Occupying Power and not on a sovereign decision by the Occupied State". ${ }^{45}$ Article 43 of The Hague Regulations mentions that

The authority of the legitimate power having in fact passed into the hands of the occupant, the latter shall take all the measures in his power to restore, and ensure, as far as possible, public order and

44 Tara Melish, op.cit., p. 191; IACHR, "Annual Report", 1993, chapter 5.

45 Jean Pictet, The Geneva Convention of 12 August 1949 Commentary..., op.cit., p. 273. 
safety, while respecting, unless absolutely prevented, the laws in force

in the country. ${ }^{46}$

The obligation to restore and ensure mentioned in this article is not an obligation of result but an obligation of means. ${ }^{47}$ The obligation of state is focused on the means to fulfil its obligation, not on the result of its actions. The article clearly states a limitation for state. Fulfilling its duty to restore and ensure public order and safety, the state has to do so "while respecting, unless absolutely prevented, the laws in force in the country. The conservationist principle under the IHL includes the obligation of occupying power to respect the laws in force in the occupied territory, the obligation to respect the institutions existing in the territory, and to respect to rights of the protected persons.

\section{a. Limitations regarding local legislation}

The Occupying Power "should respect the existing laws and economic arrangements within the occupied territory and should generally make as few changes as possible." ${ }^{48}$ One issue is relevant here, the meaning of laws as used in the relevant provisions. What does law mean? Does it include only laws, or the term is supposed to include all levels of legislative and judicial elements? The term used in Article 43 of The Hague Regulations refers to every level of legislation and not only penal laws (tax, civil, commercial laws) if they are general and abstract. ${ }^{49}$ Public order and civil life are maintained "through laws, regulations, court decisions, administrative guidelines, and even customs, all of which form an intricate and balanced system". ${ }^{50}$ Therefore, the term "laws" should be interpreted as comprising every level of the legislative or judicial element that is used to organize civil life in the occupied territory. Confirming this interpretation, Article 64(2) of the Geneva Convention IV, its wording does not make any particular reference to penal laws. Article 64(2) mentions "provisions" in general, which could be interpreted to include penal, civil, and administrative legislation. ${ }^{51}$

The wording of Article 64 of the Geneva Convention IV (essential) is less restrictive than the general prohibition of Article 43 of The Hague Regulation

46 The French version of this article is broader than the English version when speaking of "I'ordre et la vie publics" instead of "public order and safety". La vie publique implies more than just order and it includes all the elements necessary for the normal life carry on.

47 Marco Sassòli, "Legislation and Maintenance of Public Order And Civil Life By Occupying Powers", European Journal of International Law, Vol. 16 No. 4, 2005, p. 664.

48 Adam Roberts, "Transformative military occupation: applying the laws of war and human rights", American Journal of International Law, Vol. 100, 2006, p. 580; Geneva Convention Relative to the Protection of Civilian Persons in Time of War of August of 1949, p. 64.

49 Sassòli, "Legislation and maintenance of public order and civil life by occupying powers", op.cit., p. 669; Pictet, "Commentary to the Fourth Geneva Convention", op.cit., p. 335; Gasser y Dörmann, "Protection of the civilian population", p. 284.

50 Eyal Benvenisti, International Law of Occupation, USA: Princeton University Press, 1993, p. 17.

51 Sassòli, "Legislation and maintenance of public order and civil life by occupying powers", op.cit., p. 669. 
(unless absolutely prevented to respect national legislation). The later includes a material and legal necessity that needs to be fulfilled for applying the exception contained in this article. For applying the exception contained in Article 64, we only have to verify if one of the three circumstances mentioned exists. According to this article, occupying power is allowed to change the national legislations

(1) to maintain orderly government of the territory;

(2) to allow the Occupying Power to fulfill its international obligations under the Fourth Geneva Convention; and

(3) to ensure the security of the occupying power.

The IHL and the Human Rights Law limit this exception: The Occupying Power cannot introduce changes that violate both bodies of law.

Additionally, to these limitations, it is argued that The Hague Regulations and the Geneva Convention IV were negotiated and written before the major developments in the Human Rights Law occurred. Therefore, they leave aside human rights standards improvement as an exception to the conservationist principles. It is said that if those instruments were to be written today, they would include, as one of the grounds for allowing legislative changes, the improvement of human rights standards in the occupied territory.

\section{b. Limitations regarding local institutions}

Another limitation for occupying power is the prohibition to make changes on local institutions unless absolutely prevented. This item is related closely to the prohibition to change or to introduce new legislation since most of the changes in the institutions would be introduced via legislative change. Any change on the institutions through a legislative change must be made under the justification that occupying power was absolutely prevented to maintain the legislation in force. Under the Article 64(2) of the Geneva Convention IV, these alterations can be made if the three circumstances are fulfilled. In this case, other provisions of GC IV must be considered. For example, the Article 54 of the Geneva Convention IV prohibits the alteration of the status of judges and other public servants in an occupied territory. The public servants can be considered as institutions of the occupied territory and should be respected by occupying power.

\section{c. Limitations regarding protected persons}

Limitations imposed on modification of the local laws and institutions are not the only ones imposed on the Occupying Power. Having in mind that the "purpose of belligerent occupation (...) is to ensure protection for persons and objects which are no longer under the control of their own authorities but of a foreign power, and this as a result of armed conflict", the law of occupation imposes several 
limitations regarding protected persons, for example: Article 47 the Geneva Convention IV.

The changes that occupying power decides to introduce, authorized by Article 43 of The Hague Regulations or by Article 64(2) of the Geneva Convention IV, must not hamper the rights of protected persons. The wording of the quoted articles is clearly restrictive. Therefore, the prohibition in this article is stricter than the one seen in the previous articles on legislation and institutions.

\section{Transformative Occupation Approach}

The Human Rights Law treaties and customary rules are not the only ones, which impose detailed obligations to state regarding human rights. The IHL provisions may also introduce particular obligations for states. For example, under the Geneva Convention IV, occupying power must fulfill certain obligations related to human rights. Some of these obligations are mentioned in Article 3, namely the prohibitions of discrimination, torture, inhuman-and-degrading treatments, and the right to a fair trial. The Article 27(1) imposes the obligation to respect the freedom of religion (also in Article 58) and the freedom of thought. The Article 51 imposes the obligation to respect the right to work of protected persons. They are free to choose their job and cannot be compelled to work unless it is necessary for the reasons and with the guarantees mentioned in the Article. The Article 55 imposes the obligation to supply the local population with food and medical supplies. The Articles 53 and 55(2) impose the obligation to respect private property. Another example is the Article 43 of The Hague Regulations, which requires the maintenance of the public order which will include the respect for human rights in the occupied territory.

In the case of rights that are not contained in IHL provisions, the Human Rights Law still protects person and set obligations for occupying power to comply within occupied territory. In Human Rights Law, states have the possibility to limit certain rights. It is possible for state to do so when an emergency threatens the life of the nation or when it is required strictly by the exigencies of the situation. However, such limitations are possible if they are consistent with state's international obligations. State could argue that belligerent occupation following an international armed conflict amounts to a situation where it is required to limit certain rights. In any case, the limitations cannot eliminate the right as a whole. State still ought to enforce as well as respect and fulfil a minimum core of every right. This minimum core will still need to be satisfied in times of belligerent occupation and this requirement could clash with the conservative principle regarding the duties and rights of occupying power.

Facing this scenario, another approach regarding these rights and duties has been developed. Transformative occupation presents a broader perspective of 
expectation of occupying state in relation to its human rights obligations. As seen before, the extent of the changes that occupying power is allowed to introduce in occupied territory is limited to conditions and circumstances allowed (conservationist principle) by the IHL. Under the transformative occupation principle, occupying power has the right and the duty to go beyond what is allowed by the law of occupation.

The main criticism to this approach is that it would cross one of the basic characteristics of occupation: the sovereignty over that territory is not in the hands of occupying power who carries out a temporary administration. The transformative occupation implies introducing permanent and, in some cases, radical changes, exceeding the capacity in which an occupying power should act (under traditional IHL's rules). Can there be an exception to the limits imposed by IHL allowing the Occupying Power to carry a transformative occupation? Roberts mentions,

If article 64 GC IV were to be rewritten today, pressure would be applied to provide for the laws of occupation to be repealed or suspended in two additional types of circumstances - where they hamper the exercise by the inhabitants of fundamental human rights and the implementation of transformative purposes approved by the UN Security Council. ${ }^{52}$

The first scenario poses the existence of two set of rules (containing specific obligations) originating in two different areas of International Law: the International Human Rights Law and the International Humanitarian Law. This paper argues that developments on human rights would change the content of the limitations for the Occupying Power if it were drafted nowadays. In this case, it can be argued that occupying power cannot maintain the existence of flagrant and massive human rights violations in the occupied territory before the occupation. In this scenario, the later can be authorized, if it is not compelled, to introduce legislative and institutional changes. The objective of these changes would be to comply with occupying power's obligations regarding human rights of every person under its jurisdiction (subject to its jurisdiction via belligerent occupation). The IHL obligations (regarding the prohibition to introduce significant changes in legislation and institutions of the occupied territory) will yield before state's human rights obligations.

Roberts suggests another scenario: the role of the United Nations Security Council. Whether or not the authorization to introduce changes in the occupied territory given by the UN Security Council precludes the violation of IHL obligations

52 Adam Roberts, op.cit., pp. 588-589. 
(contained in article 43 of The Hague Regulations, 64(2) and 47 of the Geneva Convention IV)? This scenario refers to the possibility that the Security Council establishes rules that prevail over others that would normally apply to this situation..$^{53}$ The Article 103 of the United Nations Charter (hereinafter UN Charter) states that when there is a conflict between the obligations of state under the Charter and others arising from other legal instruments or customary international $\mathrm{law}^{54}$, the ones under the UN Charter prevail (these ones include obligations coming from Security Council resolutions which are binding ${ }^{55}$ ). Discussions have been made regarding ius cogens norms based on the Human Rights Law and the $\mathrm{IHL}$ and their superior character versus the Security Council Resolutions.

To determine the reach of the Security Council resolutions, it is necessary to determine if the law on occupation (regarding the obligation not to introduce changes in the occupied territory) can be considered as norm of ius cogens. If the norms mentioned have this rank, the UN Security Council cannot authorize state to avoid its obligations. On the other hand, if the norms mentioned are not qualified as such, the Security Council resolution could alter the obligations for state. There are different views on this matter. Some scholars consider that the IHL have ius cogens character because of its purpose to protect human beings. ${ }^{56}$ Other scholars consider that only the core of the IHL, excluding the provisions on occupation, is part of ius cogens due to its importance in the protection of human beings. It agrees with the second approach, which attributes a ius cogens character only to the most fundamental provisions of IHL. Then, the law of occupation could be restricted by a Security Council resolution.

The Security Council, based on Chapter VII, may derogate from the IHL obligations if it is "temporary, proportional, and strictly-limited to the irreducible demands of the situation. ${ }^{157}$ According to Zwanenburg, the travaux préparatoires of the UN Charter confirms this interpretation. ${ }^{58}$ Sassoli agrees that the UN Security Council can authorize some changes to be carried out by occupying power in occupied territory that would go beyond what has been authorized by IHL. "Only Security Council resolutions can justify such fundamental changes and the devolution of a wide legislative power to local authorities remaining under global control of the (former) occupying power" ${ }^{\prime 5}$ When it comes to derogations made

53 Robert Kolb, "Occupation in Iraq since 2003 and the powers of the UN Security Council", International Review of the Red Cross, 2005, pp. 31-33.

54 Marten Zwanenburg, "Existentialism in Iraq: Security Council Resolution 1483 and the law of occupation", International Review of the Red Cross, December 2004, p. 761.

55 Different interpretations have been made regarding article 25 of the UN Charter which states that " $(t)$ he Members of the UN agrre to accept and carry out the decisions of the Security Council".

56 Marco Sassòli, op.cit.,p. 1; Marten Zwanenburg, op.cit., p. 761.

57 Robert Kolb, op.cit., p. 37.

58 Marten Zwanenburg op.cit., p. 760.

59 Marco Sassòli, op.cit., p. 680. 
by the Security Council, it should be clear and not leave any room for interpretation and the Security Council must clearly establish the legal regime applicable if the IHL is no longer applicable. ${ }^{60}$ However, derogations cannot be implied.

A conclusion can be drawn, following this approach, if the standards set by national legislation are inconsistent with the international human rights standards, occupying power has to introduce changes to fulfill its international obligations since the occupied territory is under its jurisdiction. If it does not, the occupying power can breach its international law obligations. ${ }^{61}$ Sassòli mentions,

The occupying power (...) has an obligation to abolish legislation and institutions which contravene international human rights standards. While it may derogate from certain provisions due to a situation of emergency, it is certainly not obliged to do so and may therefore change any legislation contrary to the full guarantees of international human rights law. ${ }^{62}$

In our view, the ICJ in the Congo v. Uganda case has confirmed this conclusion. It is stated that the Article 43 of The Hague Regulations includes the "duty to secure respect for the applicable rules of international human rights law and international humanitarian law." ${ }^{63}$ This line of thought has been applied in various occasions. A recent example occurred in 2004, in Iraq: the Coalition Provisional Authority passed Order 89 , which prohibited child labor ${ }^{64}$ This change allowed occupying power to comply with their international obligations under the Human Rights Law, concretely the Convention on the Rights of the Child, the ILO Convention 182 on the Worst Forms of Child Labor (1999), and the ILO Convention 138 on the Minimum Age (1973).

It would be fair to conclude that nowadays the law of occupation imposing strict limits to the behavior of occupying power would recede in light of state's obligations under the Human Rights Law. Occupying power (exercising jurisdiction in its occupied territory) has the obligation to respect and fulfill the human rights consistent with human rights standards. If the changes introduced are inconsistent with the international standards, the main trend is to consider that occupying power is authorized to introduce them for human rights improvement and, by doing so, complying with its international obligations. It is clear that these changes

63 See ICJ, Case concerning the armed activities on the territory of the Congo, Democratic Republic of the Congo v. Uganda, Judgement, 2005, p. 178.

64 Coalition Provisional Authority (CPA), "Order 89: Amendments to the labor code-law N 71 of $1987^{\prime \prime}, 2004$. 
will exceed its temporary presence on the occupied territory. ${ }^{65}$ If occupying power introduced changes with long-lasting effects, the local government, once it exercises authority again, would be able to alter the changes introduced under strict parameters. Under the Human Rights Law, state is prohibited to take any retrogressive that may imply a decrease in the level of respect and fulfillment of human rights. If long-lasting changes on human rights issues were to be introduced, once an occupying power leaves its occupied territory, the local authority cannot take retroactive measure. This implies a decrease in the level of fulfillment attained by the changes introduced by the occupying power. If a state has become able to exercise jurisdiction over its previously occupied territory, then they do the measure, they violate the obligation not to adopt any retrogressive measure.

\section{Conclusion}

This paper has demonstrated that the Human Rights law is valid extraterritorially when a person or persons are subject to state's jurisdiction. Accordingly, an occupying power has to comply with its international obligations emanating from the IHL and the Human Rights Law in its occupied territory. The duties imposed by the IHL to the occupying power are clear and is in force as soon as it exercised authority and control over the territory. The obligations emanating from the Human Rights Law is in force even if the state decides to limit some of them, in accordance with the provisions regarding limitations in extreme circumstances (under the relevant treaty provisions). These obligations may be contradictory, especially under the conservationist principle contemplated by The Hague Regulations and the Geneva Convention IV. The IHL requires an occupying power to introduce small changes only if the situation really requires them. This is based on the temporal aspect of occupation: occupying power is a temporary administrator of territory. Nowadays, the conservationist principle will give way to transformative occupation approach. Occupying power is able, if it is not forced, to introduce radical changes of a permanent nature on the legislation and institutions of the occupied territory to comply with its obligations under the Human Rights Law. In this case, the Human Rights Law provisions prevail over the law of occupation.

\section{References}

\section{Books}

Benvenisti, Eyal, International Law of Occupation, Princeton University Press, USA, 1993. 
Crawford, James, State responsibility: The general part, Cambridge University Printing House, United Kingdom, 2013.

Gasser, Hans-Peter and Knut Dörmann, "Protection of the civilian population", in Dieter Fleck (ed.), The Handbook of International Humanitarian Law, OUP, United Kingdom, 2013.

Gialdino, Ronaldo, Derecho internacional de los derechos humanos: principios, fuentes, interpretación y obligaciones, Abeledo Perrot, Buenos Aires, 2013.

Melish, Tara, Protecting Economic, Social and Cultural Rights in the Inter-American Human Rights System: A Manual on Presenting Claims, CDES, Ecuador, 2002.

Monroy Cabra, Marco, Derecho Internacional Público, Ed. Temis, Colombia, 2011.

Pictet, Jean, The Geneva Conventions of 12 August 1949 Commentary - IV Geneva Convention relative to the Protection of Civilians Persons in Time of War, ICRC, Geneva, 1958.

Shaw, Malcomn, International Law, Cambridge University Press, Reino Unido, 2008.

Sorensen, Max, Manual de Derecho Internacional Público, Fondo de Cultura Económica, México, 2011.

Travieso, Juan Antonio, Derecho Internacional Público, Abeledo Perrot, Buenos Aires, 2012.

\section{Other Documents}

Carbonell, María Helena, "El deber del Estado de reparar las violaciones de derechos humanos", Cálamo Revista de Estudios Jurídicos, July 2014.

Human Rights Committee, "General Comment 29: Derogation During A State of Emergency (Article 4)”, 2001.

Human Rights Committee, "General Comment 31: The Nature of The General Legal Obligation Imposed On State Parties", 2004.

Human Rights Committee, "Lilian Celiberti de Casariego v. Uruguay", Communication No. 56/1979, 1979.

Human Rights Committee, "Sergio Euben Lopez Burgos v. Uruguay", Communication No. R.12/52, U.N.Doc. Supp. 40 (A/36/40), 1981.

Inter-American Commission on Human Rights "Armando Alejandre Jr., Carlos Costa, Mario de la Peña and Pablo Morales v. Cuba", report n 86/99, 1999.

Inter-American Commission on Human Rights, "Annual Report", 1993.

Kolb, Robert, "Occupation in Iraq Since 2003 and The Powers of the UN Security Council", International Review of the Red Cross, 2005.

Roberts, Adam, "Transformative Military Occupation: Applying The Laws Of War And Human Rights", American Journal of International Law, Vol.100, 2006.

Roberts, Adam, "What Is Military Occupation?", British Yearbook of International Law, Vol. 55 No. 1, 1984. 
Sassòli, Marco, "Legislation and maintenance of public order and civil life by occupying powers", European Journal of International Law, Vol. 16 No. 4, 2005.

Thürer, Daniel, "Current Challenges to the Law Of Occupation”, Bruges, 2005.

Zwanenburg, Marten, "Existentialism In Iraq: Security Council Resolution 1483 And The Law Of Occupation", International Review of the Red Cross, December 2004.

\section{Legal Documents}

Geneva Convention Relative to the Protection of Civilian Persons in Time of War of August of 1949, 1949.

Additional Protocol I to the Geneva Conventions of 12 August 1949 and Relating to the Protection of Victims of International Armed Conflicts, 1977.

American Convention on Human Rights, 1969.

Coalition Provisional Authority (CPA), "Order 89: Amendments to the labor codelaw N 71 of 1987", 2004.

Convention for the Protection of Human Rights and Fundamental Freedoms as amended by Protocol No. 11, 2010.

International Law Commission, "Draft articles on Responsibility of States for Internationally Wrongful Acts, with commentaries", Anuario de la Comisión de Derecho Internacional, Vol. II, Parte II, 2001.

Regulations Concerning the Laws and Customs of War on Land, Annex to the IV Convention Respecting the Laws and Customs of War on Land, 1907.

European Court of Human Rights, Loizidou vs. Turkey, chamber judgement, 1995.

2004. , Issa and others v. Turkey, chamber judgement, Saddam Hussein v. Albania, Bulgaria, Croatia, the Czech Republic, Denmark, Estonia, Hungary, Iceland, Ireland, Italy, Latvia, Lithuania, the Netherlands, Poland, Portugal, Romania, Slovakia, Slovenia, Turkey, Ukraine and the United Kingdom, Admisibility Decision, 2006.

Inter-American Court on Human Rights, Velásquez Rodríguez Case, Judgement, Ser. C No. 4, 1988.

Inter-American Commission on Human Rights, Coard et al. v. United States of America, report $\mathrm{n}^{\circ}$ 109/99, 1999.

International Criminal Tribunal for the former Yugoslavia, Prosecutor v. Mladen Naletilic and Vinko Martinovic, Trial Chamber, Merits, IT-98-34-T, 2003.

International Court of Justice, Legal Consequences of The Construction Of A Wall In The Occupied Palestinian Territories, Advisory Opinion, 2004.

Territory Of The Congo, Democratic Republic of the Congo v. Uganda, Judgement, 2005. 